\title{
Solid Sampling Analysis by Flame Atomic Absorption Spectrometry for Lead Determination in Seawater Samples after Pre-Concentration using Cocrystallized Alizarin Red - Naphthalene
}

\author{
Maria das Graças Andrade Korn ${ }^{a}$, Márcia Sousa Bispo ${ }^{a}$, Mauro Korn ${ }^{b}$, Adilson Ben da Costa ${ }^{c}$, \\ Julio Cezar Paz de Mattos ${ }^{c}$, José Neri Gottfried Paniz and Érico Marlon de Moraes Flores ${ }^{*},{ }^{c}$ \\ ${ }^{a}$ Instituto de Química, Universidade Federal da Bahia, 40170-290 Salvador - BA, Brazil \\ ${ }^{b}$ Departamento de Ciências Exatas e da Terra, Universidade do Estado da Bahia, 41195-001 Salvador - BA, Brazil \\ ${ }^{c}$ Departamento de Química, Universidade Federal de Santa Maria, 97105-900 Santa Maria - RS, Brazil
}

Um dispositivo para a amostragem direta de sólidos por espectrometria de absorção atômica com chama (DSA-FAAS) é proposto para a determinação de chumbo em água, após o procedimento de extração em fase sólida. Uma solução tampão, $\mathrm{NH}_{4} \mathrm{Cl}-\mathrm{NH}_{3}, \mathrm{pH} 8,1$, e a fase sólida (vermelho de alizarina adsorvido em naftaleno) foram adicionados a amostra de água para adsorção de chumbo. Posteriormente, as amostras (até $200 \mathrm{~mL}$ ) foram filtradas e a matriz de naftaleno foi seca, moída, até as partículas atingirem tamanho inferior a $80 \mu \mathrm{m}$ e então mantida em dessecador até a determinação de $\mathrm{Pb}$ por DSA-FAAS. Amostras sólidas (de 0,1 a $2 \mathrm{mg}$ ) foram pesadas em recipientes de polietileno, os quais foram conectados ao dispositivo para introdução direta de sólidos na chama do tipo ar + acetileno. As amostras sólidas foram transportadas na forma de um aerossol seco até uma cela de quartzo em forma de "T" que foi acoplada ao queimador e posicionada entre este e o feixe óptico do espectrômetro de absorção atômica. Na chama, o vapor atômico gerado produziu um sinal transiente que era totalmente integrado em $2 \mathrm{~s}$. O efeito das condições operacionais sobre o sinal analítico foi avaliado. Sinais de fundo foram sempre baixos $(\lambda=217,0 \mathrm{~nm})$ e não foram observados efeitos de memória. A massa característica foi de $1,1 \mathrm{ng}$ de $\mathrm{Pb}$. a calibração foi feita empregando-se diferentes massas de naftaleno impregnado com vermelho de alizarina, tratadas com soluções de referência de $\mathrm{Pb}$. Os resultados foram considerados satisfatórios para concentrações de 30 e $50 \mu \mathrm{g} \mathrm{L}^{-1}$, tanto com respeito à exatidão (recuperações de 94 a 103\%) como à precisão (desvio padrão relativo inferior a 5\%, n=6). A estabilidade de $\mathrm{Pb}$ na fase sólida (naftaleno + vermelho de alizarina) foi avaliada até 45 dias e os resultados mostraram que o material sólido, após adsorção de $\mathrm{Pb}$ e secagem) pode ser armazenado durante este período. O dispositivo proposto, usado para a introdução de amostras sólidas no atomizador, pode ser acoplado facilmente a equipamentos convencionais para espectrometria de absorção atômica.

A device for direct solid analysis by flame atomic absorption spectrometry (DSA-FAAS) with prior solid phase extraction procedure is proposed for the determination of lead in water samples. A buffer solution $\left(\mathrm{NH}_{4} \mathrm{Cl}-\mathrm{NH}_{3}, \mathrm{pH}\right.$ 8.1) and alizarin red - naphthalene solid phase were added for $\mathrm{Pb}$ sorption. After, samples (up to $200 \mathrm{~mL}$ ) were filtered and the naphthalene matrix was dried, ground to particle size $\leq 80 \mu \mathrm{m}$ and then maintained into a desiccator up to the Pb determination by DSA-FAAS. Test samples (from 0.1 to $2 \mathrm{mg}$ ) were weighed into small polyethylene vials. Vials were connected to a homemade device for solid introduction directly into a conventional air + acetylene flame. Test samples were carried as a dry aerosol to a T-quartz cell specially designed for DSA-FAAS. The T-quartz cell was positioned above the burner and below the optical path of the instrument. In the flame, the generated atomic vapor produced a transient signal that was totally integrated in $2 \mathrm{~s}$. The effect of operating conditions on the analytical signal was evaluated. Background signals were always low (wavelength $=217.0 \mathrm{~nm}$ ) and no memory effects were observed. A characteristic mass of $1.1 \mathrm{ng}$ for $\mathrm{Pb}$ was found. Calibration was performed using different masses of solid alizarin red-naphthalene spiked with $\mathrm{Pb}$ reference solution. Results were considered satisfactory, for concentration ranging from 30 and $50 \mu \mathrm{g} \mathrm{L}^{-1}$, regarding to both accuracy (recoveries from 94 to $103 \%$ ) and precision (relative standard deviation less than $5 \%, \mathrm{n}=6$ ). The stability of lead in the solid phase (naphthalene + alizarin red) was evaluated up to 45 days and the results showed that the solid material could be stored during this period. The proposed device used for solid introduction into the flame atomizer may be easily fitted to conventional atomic absorption spectrometers.

Keywords: lead, naphthalene, pre-concentration, direct solid analysis, flame atomic absorption spectrometry

\footnotetext{
* e-mail: flores@quimica.ufsm.br
} 


\section{Introduction}

Determination of trace metals in environmental samples, such seawater, is subject of extensive research since they play important roles in biological processes. Particularly, lead determination is important due to its toxicity and environmental concern. In spite of the concentration of lead in natural waters to be extremely low ( $\mu \mathrm{g} \mathrm{L}^{-1}$ or $\mathrm{ng} \mathrm{L}^{-1}$ levels), in polluted areas the $\mathrm{Pb}$ concentration can be very high. ${ }^{1}$ Nowadays, atomic spectrometry is among the most used instrumental techniques for lead determination in water. However, flame atomic absorption spectrometry (FAAS) and inductively coupled plasma optical emission spectrometry (ICP OES), two well spread techniques and relatively available in many laboratories, do not provide the necessary sensitivity for lead determination in natural waters. Therefore, a preconcentration step must be included in order to ensure the sensitivity for the determination of lead in seawater by using these conventional analytical techniques..$^{2,3}$ In adittion, by employing a pre-concentration technique, the matrix effect could be minimized since a separation of analyte from sample matrix takes place.

Several separation and pre-concentration methods for lead are described in the literature. ${ }^{4,5}$ Solid phase extraction (SPE) procedures have been reported for lead preconcentration, such as $\mathrm{Pb}$-Spec ${ }^{\mathrm{TM}},{ }^{2}$ 8-hydroxiquinoline immobilized on microporous silica ${ }^{6}$ and, silica gel modified with 3-aminopropyltriethoxysilane. ${ }^{7}$ In the last years, SPE using naphthalene has received singular attention due to its efficiency on techniques for separation and preconcentration of trace and ultra-trace species. The high extraction capacity and the easy phase separation illustrate some advantages of metal extraction with naphthalene. ${ }^{8}$ Metal chelation followed by solid phase naphthalene extraction have been applied to metal separation as demonstrated by the determination of $\mathrm{La}, \mathrm{Eu}$ and $\mathrm{Yb}$ after reaction with tribromoarsenazo - cetylpyridinium bromide and solid-liquid extraction with microcrystalline naphthalene. ${ }^{9}$ In the same way $\mathrm{Zn}, \mathrm{Cd}$ and $\mathrm{Pb}$ were determined by spectrophotometry after extraction of their morpholine-4-carbodithioates into molten naphthalene. ${ }^{10}$ Solid phase extraction with naphthalene has received attention in the last years. ${ }^{3,11}$ Recently, a procedure using alizarin red (1,2-dihydroxyanthraquinone) complexation and naphthalene as solid phase was applied for the spectrometric $\mathrm{Pb}$ determination in seawater. Using this adsorbent a 40 fold-times enrichment factor and interference removal has been reported. ${ }^{3}$

In spite of the lack of sensitivity for the usual liquid pneumatic nebulization, some procedures have been recently proposed to increase the detection capability in FAAS determinations. ${ }^{12,13}$ In other hand, the direct solid sample introduction for FAAS has been referred as a very powerful technique because of its high relative sensitivity achievable for some elements, low sample consumption, and ease of sample introduction into the atomizer. ${ }^{14-16}$ Devices for direct solid analysis (DSA) using flame atomizers present some interesting advantages compared to other procedures owing to the high throughput with a relatively low cost, and easy adaptation to conventional equipments for FAAS. In spite of the good results reported using that procedure, the use of reference materials with a very similar composition to the samples was needed to perform the calibration. This fact has been reported previously ${ }^{16}$ for the determination of $\mathrm{Cd}$ in river and marine sediments, using DSA-FAAS where multivariate calibration procedures must be used to ensure satisfactory results.

For the analysis of liquid samples a good alternative could be the coupling of SPE and DSA-FAAS, two relatively inexpensive procedures, to improve the detection limit in comparison to the ones obtained using conventional FAAS or ICP OES techniques. As an additional advantage, the separation of concomitants could minimize the interferences during the determination step. Thus, the possibility of avoiding elution steps of the analyte and minimizing the sample handling could bring some advantages for this procedure and this way, problems related to the calibration - a very common drawback in DSA procedures ${ }^{16,17}$ - should be minimized. Despite some procedures have been reported using aqueous reference solutions for calibration ${ }^{18,19}$ several DSA procedures with graphite furnace or flame atomizers are dependent on the availability of reference materials having a similar composition and analyte concentration close to the samples. ${ }^{20,21}$ However, for water samples, that problem could be solved by making the pre-concentration step by SPE using reference solutions to make the calibration curves and, after the drying and homogenizing of the adsorbent, it could be injected directly into the atomizer and analyte determinations performed by DSA-FAAS. Moreover, as naphthalene burns very quickly no excessive grinding would be need to atomization and minimum residue should remain after burn. Similar approaches using coprecipitation or synthetic materials for calibration have been previously proposed for $\mathrm{Pb}$ determination in water samples. ${ }^{22-24} \mathrm{In}$ these works very low detection limits were reported. However, in these procedures a graphite furnace, instead of a flame, was used as atomizer.

In other hand, the preservation of an analyte is an interesting analytical aspect because complete stability for every constituent can never be achieved. After sample 
collection, preservation procedures can only retard chemical and biological changes ${ }^{25}$ and, in general, analyte adsorption on the walls of vessels will take place for samples stored without acidification and/or freezing. ${ }^{26}$ Independent of storage temperature, most authors recommend acidification immediately after sampling if metal ions should be determined. Commonly, after the collection step, the samples must be filtered and stored in plastic acid washed containers at $4{ }^{\circ} \mathrm{C}$, acidified up to $\mathrm{pH} 2$ or less and the analysis must be performed as soon as possible. In this sense, the use of solid phase extraction and direct solid analysis has some advantages for preservation of trace metals after water samples collection.

Based on the considerations above, the purpose of that work was to develop a lead determination by DSA-FAAS procedure with previous pre-concentration step using a combustible solid phase as adsorbent. For that, alizarin red adsorbed on naphthalene was used to a SPE procedure. This way, calibration and sample analysis were performed using solid standards with the similar matrix composition avoiding the necessity of the use of certified reference materials, standard addition or multivariate calibration techniques.

\section{Experimental}

\section{Instrumentation}

An Analytik-Jena Model Vario 6 FL (Jena, Germany) flame atomic absorption spectrometer was used in this work. All measurements were carried using deuterium background correction. A lead hollow-cathode lamp (wavelength of $217.0 \mathrm{~nm}$, spectral slitwidth of $0.8 \mathrm{~nm}$ ), operated at $5 \mathrm{~mA}$ was used as line source. A conventional burner (air + acetylene flame, slit of $10 \mathrm{~cm}$ ) was used and the signals were measured using the integrated absorbance mode (integration time $=2 \mathrm{~s}$ ). An ultra-microbalance (Sartorius, Göttingen, Germany) model M2P with a $1 \mathrm{mg}$ resolution and a weighing range up to $2 \mathrm{~g}$ was also used. Particle size measurements of the ground naphthalene samples were made using a particle size analyzer by laser scattering (Horiba, Kyoto, Japan, model LA-300).

\section{Reagents and solutions}

All reagents were of Suprapur ${ }^{\circledast}$ or analytical grade (Merck, Darmstadt, Germany), and nitric acid was doubly distilled in subboiling system (Berghof, model BSP 929, Germany). Ultrapure water from Milli- ${ }^{\circledR}$ water purification system (Millipore, Bedford, USA) was used to prepare all solutions. The laboratory glassware was kept overnight in a $10 \%$ nitric acid solution. Before its use, the glassware was washed with deionized water and dried in a dust-free environment.

\section{Preparation of alizarin red-naphthalene solid phase and} sorption lead procedure

For the sorption procedure a suitable volume of analytical solution containing 10,20 and $50 \mu \mathrm{g}$ of lead was added to glass vessels containing each one $200 \mathrm{~mL}$ of buffer $\left(\mathrm{NH}_{4} \mathrm{Cl}-\mathrm{NH}_{3}, \mathrm{pH} 8.1\right)$. Then $0.5 \mathrm{~g}$ of the solid phase (naphthalene) was added and the vessels were capped. That procedure was performed in triplicate. Vessels were mechanically shaken for 5 minutes for quantitative lead sorption. The preparation procedure of the alizarin rednaphthalene solid phase used for the lead preconcentration step was previously described. ${ }^{3}$ Lead concentrations resulting in the solid phases were 20,50 and $100 \mu \mathrm{g} \mathrm{g}^{-1}$. The solid phase was dried in a desiccator, manually ground and homogenized in an agate mortar at particle size fractions $\leq 80 \mu \mathrm{m}$. The stability of lead retained in the solid alizarin red-naphthalene matrix was studied up to a period of 45 days after the sorption step.

\section{Direct solid analysis device for $\mathrm{Pb}$ determination}

The device used in this work for direct solid introduction into the flame was described in previous works. ${ }^{14,27}$ Test samples of solid alizarin red-naphthalene with lead adsorbed were directly weighed ( 0.1 to $2 \mathrm{mg}$ ) into polyethylene (PE) vials. After, vials were connected to the device used to sample introduction ${ }^{14}$ into the flame and samples were carried out as a dry aerosol through a heated quartz cell and then dispersed into a conventional air-acetylene flame. The total air flow-rate passing through the quartz T-cell was kept constant during all steps (5 L $\mathrm{min}^{-1}$ ). The transient signals for lead were completely recorded in less of $1 \mathrm{~s}$ (a total integration time of $2 \mathrm{~s}$ was used to detect any memory effect.

\section{Results and Discussion}

Optimization conditions for the proposed SPE-DSA-FAAS procedure

Initially the behavior of dried and ground naphthalene matrix was evaluated (particle size $\leq 80 \mu \mathrm{m}$ ) using the device to direct solid introduction into the flame. The tests were made using $0.4 \mathrm{mg}$ of the alizarin red - naphthalene solid phase with lead concentration of $\left.50 \mu \mathrm{g} \mathrm{g}^{-1}\right)$. The influence of some parameters was considered: T-quartz cell 
distance in relation to the optical path as well as the effect of flame composition on the absorbance signals. The tested distance between T-quartz cell and the optical path varied from 2 to $10 \mathrm{~mm}$ and, with the exception of $2 \mathrm{~mm}$, no significant differences $(\mathrm{P}<0.05)$ in sensitivity were observed for all other evaluated distances. With the distance of $2 \mathrm{~mm}$ a higher standard deviation was observed and sensitivity was lower than the correspondent values for other distances studied. It could be due to an insufficient time to the complete atomization step. The characteristic masses obtained were around $1.1 \mathrm{ng}$ with distances varying from 4 to $10 \mathrm{~mm}$ and the relative standard deviation was less than $4.5 \%$. The distance of $4 \mathrm{~mm}$ was chosen for subsequent studies due to the smaller standard deviation.

In previous works where a similar T-quartz cell device to DSA-FAAS was used, it was observed the non-dependence of the distance between the T-quartz cell and the burner head. For the determination of other elements $(\mathrm{Cu}, \mathrm{Cd}$ and $\mathrm{Mn}$ ) in different matrices ${ }^{14,16}$ the influence of distance on the absorbance signals was considered having a minor effect and the distance of $5 \mathrm{~mm}$ (slightly better) was chosen for all other DSA-FAAS procedures using the same system. It was expected that the thermal behaviour of naphthalene should be similar to other organic samples as well as the analyte residence time in optical path. As the internal temperature of the T-quartz cell is less than the flame temperature it is probable that the atomization process occurs in the flame. Than, the distance between the quartz cell and optical path is an important parameter in view of to choose the better observation zone and, of course, better sensitivity.

In this work the same value for that distance was arbitrarily chosen and no attempts were made to evaluate the influence of other distances. The influence of flame composition on $\mathrm{Pb}$ signals was also studied. For this study the acetylene flow was kept constant at $120 \mathrm{~L} \mathrm{~h}^{-1}$ and the airflows was varied from 500 to $700 \mathrm{~L} \mathrm{~h}^{-1}$. Results are shown in Figure 1. A high variation in the characteristic mass was observed (from 1.1 to $5.0 \mathrm{ng}$ ) and the best sensitivity was

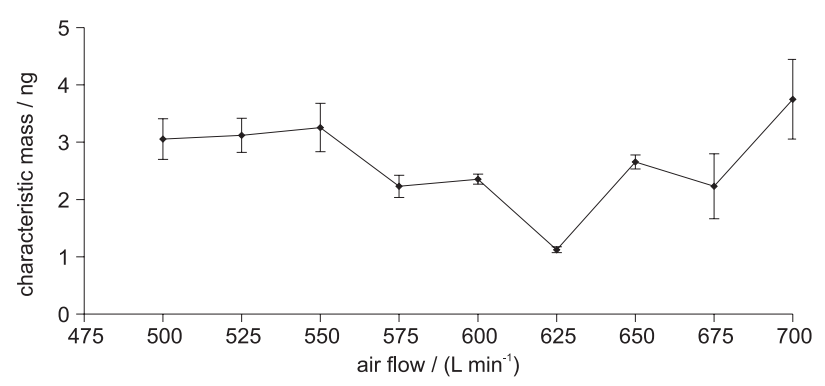

Figure 1. Influence of flame composition (acetylene flow fixed to $\left.120 \mathrm{~L} \mathrm{~h}^{-1}\right)$ on the characteristic mass for $\mathrm{Pb}$ determination in the naphthalene solid phase. Air flow in the sampling chamber: $5 \mathrm{~L} \mathrm{~min}^{-1}$; distance between the burner and quartz T-cell: $5 \mathrm{~mm}$; bars represent the relative standard deviation $(n=6)$. obtained for $625 \mathrm{~L} \mathrm{~h}^{-1}$ airflow. The effect of flame composition on the analytical signal did not present a regular behavior. This fact should be an effect of the sum of some factors such as the flow, temperature and kind of flame (if oxidant or reducing). Thus, the $120+625 \mathrm{~L} \mathrm{~h}^{-1}$ acetylene + air mixture was chosen for further experiments.

Possible memory effects were evaluated by using empty vials and recording the absorbance signal just after injected solid test samples. However, the obtained signals were always insignificant and very close to the baseline in spite of the use of relatively high sample masses (up to $2 \mathrm{mg}$ ) introduced into the flame.

At the optimized conditions reproducible absorbance signals and surprisingly low background signals were obtained (no solid particles were observed during naphthalene combustion). Figure 2 shows a typical analytical signal for $\mathrm{Pb}$ using the proposed DSA-FAAS system. As can be seen, the shape of absorbance signal is very symmetric, returns quickly to the baseline and could be integrated in a very short time. It is important to realize that the signals were recorded without the use of any smoothing procedure. Background signals were always low (lower than 0.2 in peak height absorbance scale) for all investigated instrumental conditions.

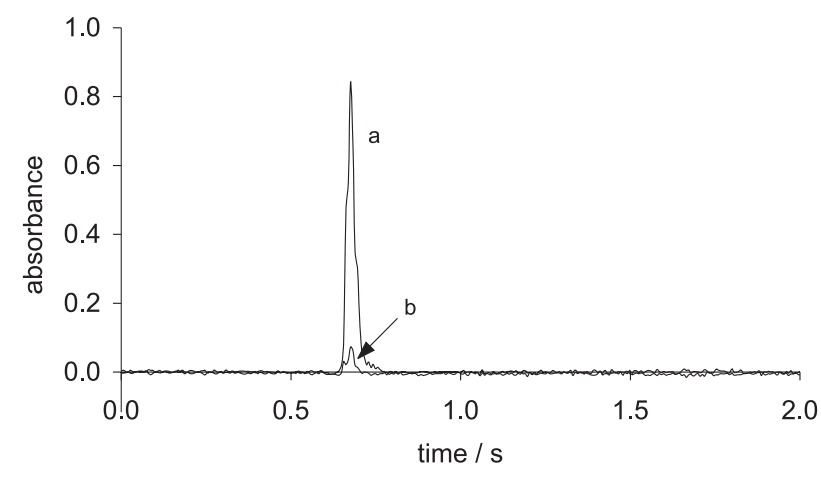

Figure 2. Typical absorbance profiles for (a) $\mathrm{Pb}$ analytical signal and (b) background for $0.5 \mathrm{mg}$ of a solid phase (the lead concentration in the solid phase was $15 \mathrm{mg} \mathrm{g}^{-1}$ ) by the proposed SPE-DSAFAAS procedure under optimized conditions. Flame composition: air $\left(625 \mathrm{~L} \mathrm{~h}^{-1}\right)$ and acetylene $\left(120 \mathrm{~L} \mathrm{~h}^{-1}\right)$; air flow in the sampling chamber: $5 \mathrm{~L} \mathrm{~min}^{-1}$.

Another study was made to verify the stability of the dried solid matrix alizarin red-naphthalene with $\mathrm{Pb}$ sorbed. After the sorption process, test-samples were stored and lead determination was performed. It was observed that the $\mathrm{Pb}$ sorbed was stable in the naphthalene matrix for a 45 daysperiod without changes of the initial $\mathrm{Pb}$ concentration (relative standard deviation less than 5\% if the solid is stored in closed vessels). The matrix stability is important because water samples can be treated by the SPE procedure and be stored up to the final $\mathrm{Pb}$ determination when convenient. 
An important aspect on the atomization process for DSA-FAAS procedures is related to the particle size due to the characteristic of heating transference and residence time in the flame. Obviously, the atomization is dependent on the design of the solid introduction system and the kind of sample matrix. As naphthalene is combustible, few drawbacks should be expected due to the relatively high particle size. The determination of the number of particles in sub-fractions of 5 to $5 \mathrm{~mm}$ for the selected granulometric fraction. The results showed that at least $85 \%$ of the particles were below $30 \mathrm{~mm}$ for the " $\leq 80 \mu \mathrm{m}$ " fraction and they could explain the facility of atomization using the proposed procedure. In this work no attempts were made to grind the samples to a granulometry less than $80 \mathrm{~mm}$. This choice was made based on the following aspects: $(i)$ the selected particle size was the same currently chosen in previous works using the same device for analysis by DSAFAAS, ${ }^{14-16}(\mathrm{ii})$ as the test samples are pre-heating into the T-quartz cell (passing as a dry aerosol just before entering into the flame) some reduction on the particle size could be assumed and (iii) avoiding excessive grinding it can minimize the time involved to the sample preparation (about $20 \mathrm{~min}$ are need to achieve the selected particle size using a manual agate mortar).

\section{Calibration}

As previously commented, analytical curves were performed using test-samples from three different synthetic reference naphthalene matrices having $\mathrm{Pb}$ concentrations in the solid phase correspondent to 20,50 and $100 \mu \mathrm{g} \mathrm{g}^{-1}$. It was observed a good correlation $\left(\mathrm{R}^{2}=0.9827\right)$ among the different $\mathrm{Pb}$ masses relative to the three synthetic naphthalene reference samples. Results are presented in Figure 3 . The curve was constructed with 45 points with a minimum of 10 points for each test sample, each one

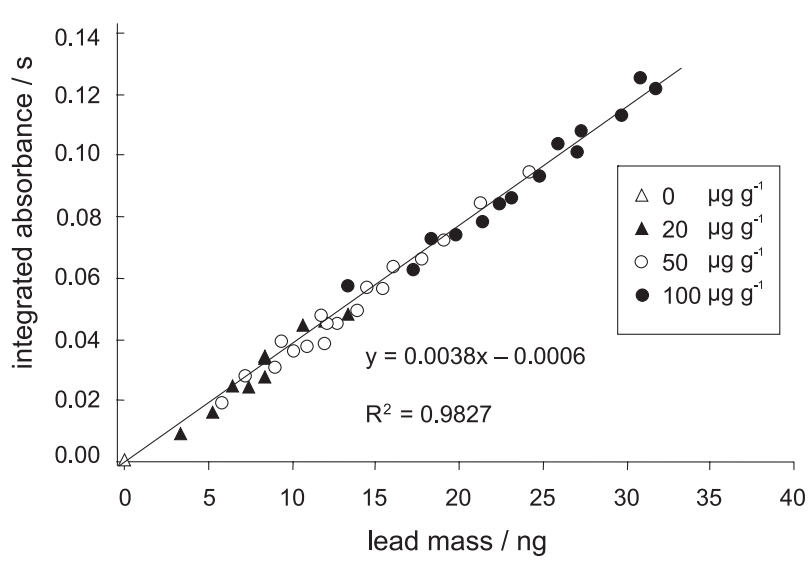

Figure 3. Correlation between absorbance and mass of lead (sample mass from 0.1 to $0.5 \mathrm{mg}$ ) in different alizarin red-naphthalene solid phase samples using the proposed procedure. generated from a single measurement. The use of more than 40 points to construct the analytical curve was performed only to demonstrate the good correlation and linearity for the proposed SPE-DSA-FAAS procedure and, obviously, fewer points should be needed to calibration for routine analysis. The correlation obtained could be a good indicative for the evaluation of $\mathrm{Pb}$ sorption process by SPE.

\section{Figures of merit}

Table 1 presents the figures of merit and some optimized conditions for the proposed SPE-DSA-FAAS procedure. A characteristic mass of $1.1 \mathrm{ng} / 0.0044 \mathrm{~s}$ was obtained for sample masses ranging from 0.1 to $3 \mathrm{mg}$. The instrumental limit of detection was $0.9 \mathrm{ng}(3 \mathrm{~s}, \mathrm{n}=10)$ and the limit of the quantification was $3 \mathrm{ng}(10 \mathrm{~s}, \mathrm{n}=10)$. Relative standard deviation was smaller than $5 \%$. Therefore, this proposed procedure could be used for the separation and preconcentration of the lead in water samples allowing a limit of quantification for $\mathrm{Pb}$ around $2.5 \mu \mathrm{g} \mathrm{L}^{-1}$ in water, if considering a sample volume of $200 \mathrm{~mL}$. This limit is very close to that previously reported by using the same SPE procedure but performed with ICP OES for $\mathrm{Pb}$ determinations $^{3}$ and it was considered sufficient to the evaluation of environmental contamination by $\mathrm{Pb}$. However, it is important to have in mind that in the proposed procedure a simple and conventional airacetylene flame is used as atomizer. According to the Brazilian environment regulation (Class II waters) the maximum $\mathrm{Pb}$ concentration in water is $30 \mu \mathrm{g} \mathrm{\textrm {L } ^ { - 1 }}$. $^{28}$

Table 1. Figures of merit and optimized conditions for the proposed SPE-DSA-FAAS procedure

\begin{tabular}{ll}
\hline Parameters & \\
\hline Limit of detection & $0.9 \mathrm{ng}$ (absolute) \\
Limit of quantification & $3 \mathrm{ng}$ (absolute) \\
& $2.5 \mu \mathrm{g} \mathrm{L}$ (sample) \\
& $1.1 \mathrm{ng} / 0.0044 \mathrm{~s}$ \\
Characteristic mass & $5 \mathrm{~L} \mathrm{~min}-1$ \\
Air flow in the sampling chamber & air: $625 \mathrm{~L} \mathrm{~h}^{-1}$ and \\
Flame composition & $\mathrm{C}_{2} \mathrm{H}_{2}: 120 \mathrm{~L} \mathrm{~h}^{-1}$ \\
& $5 \mathrm{~mm}$ \\
Distance between quartz T-cell and burner & $4 \mathrm{~mm}$ \\
$\begin{array}{l}\text { Distance between quartz T-cell and } \\
\text { optical path }\end{array}$ & $\leq 80 \mu \mathrm{m}$ \\
Particle size & $<5 \%(\mathrm{n}=10)$ \\
Relative standard deviation &
\end{tabular}

The proposed SPE-DSA-FAAS procedure was applied for the determination of $\mathrm{Pb}$ in seawater samples collected in Tramandai beach (Rio Grande do Sul state, Brazil) and all values for $\mathrm{Pb}$ concentration were below the quantification limit $\left(2.5 \mu \mathrm{g} \mathrm{L}^{-1}\right)$. Lead was added to these 
three samples correspondent to 30 and $50 \mu \mathrm{g} \mathrm{L}^{-1}$ and the recoveries using the proposed procedure were from 94 to $103 \%$ for all samples $(n=6)$.

Concerning to the sample throughput, it was possible to perform more than 40 determinations per hour after the SPE procedure and weighing of the samples. An interesting aspect related to the routine analysis, for samples that have been collected far from the laboratory for measurement, is related to the possibility to have near to the collection site a laboratory with simple equipments (balance, oven, desiccator, etc) without the necessity of the equipment for measurements as spectrometers for FAAS or ICP OES. Thus, in spite of the possibility of $\mathrm{Pb}$ determination in sea waters by electrothermal atomic absorption spectrometry, ${ }^{29,30}$ with the proposed procedure using FAAS, a less expensive technique, is possible to obtain a satisfactory performance. As the analyte adsorbed in the cocrystallized alizarin rednaphthalene is stable, samples can be treated by the SPE procedure and preserved in plastic vials until $\mathrm{Pb}$ determination.

One aspect must be considered: as the solids used for calibration must have similar matrix composition, the proposed procedure minimizes a usual problem related to the reference materials availability having suitable analyte concentration for the calibration step. Thus, as the $\mathrm{Pb}$ adsorbed alizarin red - naphthalene matrix is stable, at least, by 45 days it is possible to keep a lot of ground reference test-samples in the laboratory by preparing synthetic solid calibration samples having a convenient interval of $\mathrm{Pb}$ concentration. Therefore, the calibration can be performed by direct comparison among the absorbance signals of solids having virtually the same properties. It means that no sophisticated calibration such as multivariate or $3 \mathrm{D}$ procedures should be involved. ${ }^{16}$ In addition, using test-sample masses of $3 \mathrm{mg}$, is possible, after drying the solid adsorbent, to perform more than 250 replicates from the same test-sample taking into account a naphthalene mass of $0.5 \mathrm{~g}$.

In this work background signals using the DSA-FAAS procedure were always low and memory effects were virtually absent. However, a limitation of the proposed procedure is the maximum sample mass, restricted to 3 mg. This fact limits the detection limit achievable by that procedure, no problems were observed in this work concerning to the homogeneity. On the other hand, the SPE-DSA-FAAS procedure can be considered a low-cost procedure. The device for solid introduction into the flame can be easily fitted to conventional flame atomic absorption spectrometers and then allow the determination step more accessible to laboratories for routine $\mathrm{Pb}$ determination in water samples.

\section{Acknowledgments}

Authors thank to CAPES, FINEP, FAPERGS, CNPq/ FAPESB (Proc. No 40/03) and CNPq, for supporting this study and to Dr. Marco A. Z. Arruda (UNICAMP, SP, Brazil) by the particle size measurements.

\section{References}

1. Manahan, S.E.; Environmental Chemistry, $6^{\text {th }}$ ed., Lewis: Boca Raton, USA, 1994.

2. Seki, T.; Hirano, Y.; Oguma, K.; Anal. Sci. 2002, 18, 351.

3. Korn, M.G.A.; Bispo, M.S.; Boa Morte, E.S.; Teixeira, L.S.G.; Spectrochim. Acta Part B 2002, 57, 2175.

4. Pereira, M.G.; Arruda, M.A.Z.; Microchim. Acta 2003, 141, 15.

5. Cave, M.R.; Butler, O.; Chenery, S.R.N.; Cook, J.M.; Cresser, M.S.; Miles, D.L.; J. Anal. At. Spectrom. 2001, 16, 194.

6. Lofthouse, S.D.; Greenway, G.M.; Stephen, S.C.; J. Anal. At. Spectrom. 1999, 14, 1839.

7. Tokman, N.; Akman, S.; Ozcan, M.; Talanta 2003, 59, 201.

8. Costa, A.C.S.; Lopes, L.; Korn, M.G.A.; Portela, J.G.; J. Braz. Chem. Soc. 2002, 13, 674.

9. Cai, B.; Hu, B.; Xiong, H.; Liao, Z.; Mao, L.; Jiang, Z.; Talanta 2001, 55, 85 .

10. Sethi, C.L.; Puri, B.K.; Satake, M.; Microchem. J. 1986, 33, 179.

11. Yebra, M.C.; Carro, N.; Moreno-Cid, A.; Puig, L.; Field Anal. Chem. Technol. 2001, 5, 239.

12. Berndt, H.; Gáspár, A.; Spectrochim. Acta Part B 2000, 55, 587.

13. Berndt, H.; Davies, J.; Anal. Chim. Acta 2003, 479, 215.

14. Flores, E.M.M.; Costa, A.B.; Barin, J.S.; Dressler, V.L.; Paniz, J.N.G.; Martins, A.F.; Spectrochim. Acta Part B 2001, 56, 1875.

15. Flores, E.M.M.; Paniz, J.N.G.; Martins, A.F.; Dressler, V.L.; Müller, E.I.; Costa, A.B.; Spectrochim. Acta Part B 2002, 57, 2187.

16. Flores, E.M.M.; Paniz, J.N.G.; Saidelles, A.P.F.; Müller, E.I.; Costa, A.B.; J. Anal. At. Spectrom. 2003, 18, 769.

17. Kurfürst, U.; Solid Sample Analysis, Springer Verlag: Berlin, 1998.

18. Silva, A.F.; Welz, B.; Curtius, A.J.; Spectrochim. Acta B 2002, 57, 2031.

19. Krivan, V.; Huang, M.D.; Fresenius J. Anal. Chem. 2000, 368 , 227.

20. Belarra, M .A.; Resano, M.; Vanhaecke, F.; Moens, L.; Trends Anal. Chem. 2002, 21, 828.

21. Welz, B.; Vale, M.G.R.; Silva, M.M.; Lima, E.C.; Spectrochim. Acta B 2001, 56, 1859.

22. Akatsuka, K.; Atsuya, I.; Anal. Chem. 1989, 61, 216. 
23. Akatsuka, K.; Atsuya, I.; Fresenius Z. Anal. Chem. 1987, 329, 453.

24. Atsuya, I.; Itoh, K.; Fresenius Z. Anal. Chem. 1988, 329, 750.

25. American Public Health Association; Standard Methods for Examination of Water and Wastewaters, $19^{\text {th }}$ ed., American Public Health Association: Washington, DC, 1995.

26. Stoeppler, M.; Sampling and Sample Preparation, Elsevier, Berlin, 1997.

27. Flores, E. M. M.; Saidelles, A. P. F.; Flores, E. L. M.; Mesko, M. F.; Pedroso, M. P.; Dressler, V. L.; Bittencourt, C. F.; Costa, A. B.; Microchem. J. 2004, 77, 113.
28. CONAMA - Conselho Nacional do Meio Ambiente, Resolução N. 20, 18 de junho de 1986, Brasília, 1986.

29. Volynsky, A.B.; Akman, S.; Dogan, C.E.; Koklu, U.; Spectrochim. Acta B 2001, 56, 2361.

30. Acar, O.; Kiliç, Z.; Türker, A.R.; Anal. Chim. Acta 1999, 382, 329.

Received: November 3, 2004 Published on the web: October 06, 2005 